\title{
EFEKTIFITAS MODEL PEMBELAJARAN INSIDE OUTSIDE CIRLE TERHADAP HASIL BELAJAR SISWA PADA MATA PELAJARAN IPA SD FRANSISKUS BATURAJA
}

\author{
Siti Muyaroah \\ Universitas Baturaja \\ Siti_muyaroah@fkip.unbara.ac.id
}

\begin{abstract}
This research aims to determine the effectiveness of learning models inside outside circle of student learning outcomes on science subjects 2 nd class SD Fransiskus Baturaja. This research is quantitative research with experimental method. Can be interpreted as the research methods used to find a specific treatment effect against the other in a state of control. This ressearch result in the effectiveness of learning models inside outside circle for student learning outcomes on science subjects. Effectiveness is the success of an establishment of a system designed to engage students actively and independently in learning. T-test result there are effectiveness of of learning models inside outside circle of student learning outcomes on science subjects.
\end{abstract}

Keywords: Efektifitas, Inside Outside Circle, Science Subjects

\begin{abstract}
Abstrak
Penelitian ini bertujuan untuk mengetahui efektifitas model pembelajaran inside outside cirle terhadap hasil belajar siswa pada mata pelajaran IPA di kelas II SD Fransiskus baturaja. Penelitian ini merupakan merupakan penelitian kuantitatif dengan metode eksperimen dapat diartikan sebagai metode penelitian yang digunakan untuk mencari pengaruh perlakuan tertentu terhadap yang lain dalam kondisi terkendalikan. Penelitian ini menghasilkan adanya efektitas model pembelajaran inside outside cirle terhadap hasil belajar mata pelajaran IPA. Keefektifan yang dimaksud dalam penelitian ini adalah keberhasilan tentang suatu usaha dari sistem yang dirancang untuk melibatkan siswa secara aktif dan mandiri dalam pembelajaran. Hasil uji-t menyatakan bahwa terdapat keefektifan penggunaan model pembelajaran inside outside cirle terhadap hasil belajar mata pelajaran IPA dengan hasil belajar yang di dapat siswa.
\end{abstract}

Kata Kunci: Efektifitas, Inside Outside Circle, IPA

\section{A. PENDAHULUAN}

Penyelenggaraan pendidikan yang mengarah pada sumber daya manusia yang menyeluruh bermaksud untuk menciptakan sumber daya manusia yang berkualitas. Unsur utama yang sangat berperan dalam mencapai tujuan pembelajaran adalah seorang guru. Oleh karena itu, kualitas guru yang mengajar sangat mempengaruhi pendidikan suatu bangsa. Dengan usaha dan kreatifitas serta kemampuan guru menggunakan berbagai strategi dan model pembelajaran supaya siswa dapat mencapai tujuan pembelajaran dengan maksimal. Supaya tujuan itu tercapai, maka seorang guru harus mampu menciptakan suasana belajar yang kondusif dan dapat mengembangkan kemampuan peserta didik.

Untuk meningkatkan kualitas pembelajaran, diperlukan sebuah paradigma 
baru oleh seorang guru dalam proses pembelajaran, dari yang semula pembelajaran berpusat pada guru menuju pembelajaran inovatif yang berpusat pada siswa. Perubahan itu dimulai dari model pembelajaran maupun cara mengajar. Pada zaman modern ini masih ada guru yang mengajar menggunakan metodologi mengajar tradisional. Cara belajar tersebut berpusat pada guru (teacher centered). Kegiatan pembelajaran berpusat pada guru, sedangkan siswa hanya sebagai objek bukan sebagai subjek belajar. Guru memberikan ceramah dan siswa hanya mendengarkan. Pembelajaran yang seperti ini akan cenderung membuat siswa bosan sehingga sulit untuk mencerna materi. Metodologi mengajar secara tradisional menjadikan siswa tidak bebas untuk mengemukakan pendapatnya. Mereka akan takut disalahkan apabila jawabannya salah sehingga mereka kesulitan untuk menemukan dan mengembangkan potensi yang ada pada dirinya. Siswa menganggap guru mengetahui segalanya. Selain itu, komunikasi yang terjadi juga hanya komunikasi satu arah dari guru ke siswa.

Salah satu hal yang mempengaruhi proses belajar mengajar adalah emosi. Apabila siswa merasa terpaksa dalam mengkuti suatu pelajaran, mereka akan kesulitan menerima pelajaran atau materimateri yang diberikan oleh guru. Faktor lain yang menjadi penyebabnya adalah cara mengajar guru yang lebih banyak berfungsi sebagai instruktur yang aktif dan siswa sebagai penerima pengetahuan yang pasif. Siswa hanya mendengarkan, mencatat, dan mengulang lagi di rumah untuk menghadapi ulangan. Pembelajaran yang seperti inilah yang dapat membuat siswa pasif, bosan dan membuat pembelajaran menjadi tidak bermakna.

Maka dari itu, guru harus dapat menciptakan suasana yang kondusif dan membuat pembelajaran menjadi efektif dan menyenangkan. Guru perlu memahami hal-hal yang mempengaruhi proses belajar peserta didik, baik yang mendukung ataupun yang menghambat. Guru juga harus memahami tentang model atau strategi pembelajaran yang efektif untuk membantu pencapaian prestasi belajar yang lebih baik dan meningkatkan keaktifan siswa dalam proses belajar mengajar.

Inside outside circle adalah model pembelajaran dengan sistem lingkaran kecil dan lingkaran besar yang diawali dengan pembentukan kelompok besar dalam kelas yang terdiri dari kelompok lingkaran dalam dan kelompok lingkaran luar". Proses pembentukan kelompok memiliki karakteristik yang berbeda setiap siswa. Setiap siswa akan mencari informasi dan saling bertukar informasi dan pengetahuan yang didapat sendiri satu dengan yang lain, sehingga dapat memecahkan permasalahan secara bersama- sama" (Shoimin, 2014:87). Adapaun tujuan dari penelitian ini adalah untuk mengetahui adanya efektifitas model pembelajaran inside outside cirle terhadap hasil belajar siswa pada mata pelajaran IPA di kelas II SD Fransiskus Baturaja.

\section{B. KAJIAN LITERATUR}

1. Konsep Belajar dan Pembelajaran

Belajar merupakan hal yang kompleks. Kompleksitas belajar tersebut dipandang dari dua subjek, yaitu dari mahasiswa dan dari dosen. Dari segi siswa, belajar dialami sebagai suatu proses mental dalam mengahadapi bahan belajar. Sedangkan dari segi guru, proses belajar tersebut tampak sebagai perilaku belajar tentang sesuatu hal. Dimyati dan Mudjiono (2009:7) "belajar merupakan tindakan dan perilaku siswa yang kompleks. Sebagai tindakan, maka belajar hanya dialami oleh siswa sendiri. Panen (2004:1) "Belajar adalah suatu proses perubahan yang relatif tetap dalam perilaku individu sebagai hasil 
dari pengalaman". Sedangkan, Ruhimat (2011:124) "Belajar merupakan aktivitas yang disengaja dan dilakukan oleh individu agar terjadi perubahan kemampuan diri, dengan belajar anak yang tadinya tidak mampu melakukan sesuatu, menjadi mampu melakukan sesuatu, atau anak yang tadinya tidak terampil, menjadi terampil". Ruhimat, dkk (2011:128), "Pembelajaran adalah suatu upaya yang dilakukan oleh seseorang atau pendidik untuk membelajarkan mahasiswa yang belajar". Kustandi dan Sutjipto (2011:5) "pembelajaran merupakan suatu usaha sadar guru/pengajar untuk membantu siswa atau anak didiknya, agar mereka dapat belajar sesuai dengan kebutuhan minatnya" Sedangkan menurut Trianto (2013:19), "pembelajaran merupakan aspek kegiatan manusia yang kompleks, yang tidak sepenuhnya dapat dijelaskan.

Pembelajaran secara simpel dapat diartikan sebagai produk interaksi berkelanjutan antara pengembangan dan pengalaman hidup". Shoimin (2014:23) "model pembelajaran adalah kerangka konseptual yang melukiskan prosedur yang sistematis dalam mengorganisasikan pengalaman belajar untuk mencapai tujuan belajar tertentu, dan berfungsi sebagai pedoman bagi para perancang pembelajaran dan para pengajar dalam merencanakan aktivitas belajar mengajar." Joyce dan Weil dalam Rusman (2012:133), "model pembelajaran adalah suatu rencana atau pola yang dapat digunakan untuk membentuk kurikulum (rencana pembelajaran jangka panjang), merancang bahan- bahan pembelajaran, dan membimbing pembelajaran di kelas atau yang lain."

2. Model Pembelajaran Inside Outside circle
Inside Outside Cricle (lingkaran dalam-lingkaran luar) merupakan model pemebelajran kooperatif, dirancang khusus secara berkelempok agar megasih keterampilan berkomunikasi siswa.

Shoimin (2014:87) mengatakan bahwa "inside outside circle adalah model pembelajaran dengan sistem lingkaran kecil dan lingkaran besar yang diawali dengan pembentukan kelompok besar dalam kelas yang terdiri dari kelompok lingkaran dalam dan kelompok lingkaran luar". Adapun tujuan dari teknik pembelajaran inside outside circle ini adalah siswa dapat berbagai informasi pada waktu yang sama (bersamaan). Teknik ini dapat mengasah keterampilan berkomunikasi, siswa berkesempatan mengolah informasi, teknik ini juga berpotensi mengaktifkan anak yang dirasa pasif menjadi aktif.

Hal tersebut sesuai dengan kajian Barsihanor (2016) bahwa teknik inside outside circle memilki pengaruh yang positif dari circle terhadap hasil belajar siswa bidang Studi IPS di MI Darul Mujahidin.

Ningsih dan Andriani (2016) terdapat 11 langkah model pembelajaran Inside Outside Circle adalah seabagai berikut: Guru membagi siswa menjadi kelompok yang terdiri dari 3-4 orang; Tiap-tiap kelompok mendapat tugas mencari informasi berdasarkan pembagian tugas dari guru; Setiap kelompok belajar mandiri, mencari informasi berdasarkan tugas yang diberikan; Setelah selesai, seluruh siswa berkumpul membaur (tidak berdasarkan kelompok); Separuh kelas lalu berdiri membentuk lingkaran kecil dan menghadap keluar; Separuh kelas lainnya membentuk. lingkaran diluar lingkaran pertama, menghadap kedalam; 
Dua siswa yang berpasangan dari lingkaran kecil dan besar berbagi informasi. Pertukaran informasi ini bisa dilakukan oleh semua pasangan dalam waktu yang bersamaan; Kemudian siswa berada di lingkaran kecil diam ditempat, sementara siswa yang berada di lingkaran besar bergeser satu atau dua langkah searah jarum jam; Sekarang giliran siswa berada di lingkaran besar berbagi informasi. Demikian seterusnya, sampai seluruh siswa selesai berbagi informasi; Pergerakan baru dihentikan jika anggota kelompok lingkaran dalam dan luar sebagai pasangan asal bertemu kembali; dan Guru memberikan evaluasi atau latihan soal mandiri.

\section{METODOLOGI PENELITIAN}

Penelitian ini menggunakan metode eksperimental dengan rancangan penelitian Subject Posttest Only Control Group Design. Teknik pengambilan sampel dalam penelitian ini adalah menggunakan teknik cluster random sampling.

Teknik pengumpulan data dengan metode tes untuk mengetahui hasil belajar asiswa pada mata pelajaran IPA dan hasil belajar. Analisis data pada penelitian ini menggunakan statistik uji-t. Teknik analisa data yang digunakan dalam penelitian ini menggunakan teknik statistik uji-t (t-test). Uji- $T$ digunakan untuk membandingkan kelas perlakuan yaitu pre test dan post test.

\section{HASIL DAN PEMBAHASAN}

Dalam penelitian ini, peneliti akan memaparkan hail analisa pada variabel yang diolah dengan teknik sebagai berikut:

\section{Tabel 1}

Tabel Post Test dan Pre Test

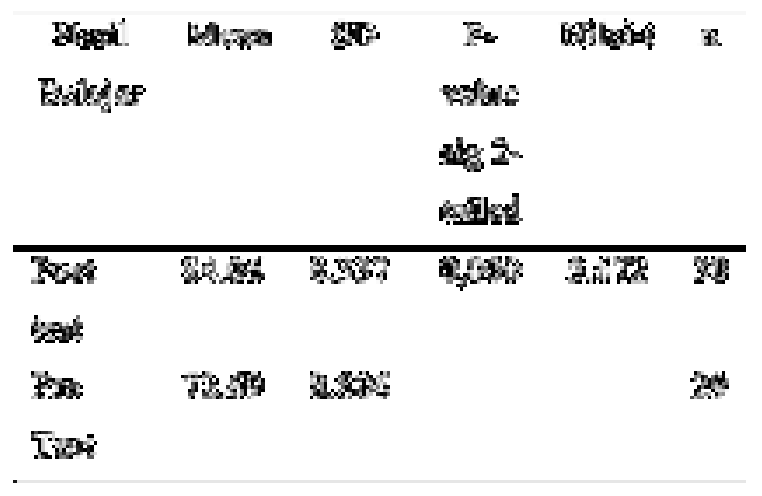

Berdasarkan perhitungan di atas, di hasilkan bahwa pada kelas kontrol nilai rataratanya sebesar 72,69 sedangkan kelas eksperimen sebesar 84,06. Sedangkan pada uji efektifitas nilai thitung sebesar 5,672. Sedangkan nilai ttabel untuk $\mathrm{n}$ sebesar 30 yaitu 1,703 .

Berdasarkan hasil uji perbedaan nilai rata- rata nilai kelas terdapat perbedaan nilai sebelum mengguakan menggunakan model pembelajaran inside outside circle serta nilai setelah menggunakan model menggunakan model pembelajaran inside outside circle pada mata pelajaran IPA. Peningkatan nilai hasil belajar terjadi karena meningkatnya motivasi belajar siswa dengan menggunakan model pembelajaran inside out side circle. Hasil kajian yang dilakukan oleh Faradila, Sulistyaningsih, Purnomo (2017). bahwa pembelajaran dengan menggunakan model pembelajaran Inside Outside Circle dengan pendekatan Open Ended dapat membuat siswa lebih semangat dalam kegiatan pembelajaran berpasangan seperti itu membuat siswa tidak mudah bosan dan mampu melatih perserta didik untuk terbiasa mengerjakan soal-soal latihan secara individual dan berpasang. Hal ini sesuai dengan pendapat sardiman (2014:85) yang menyatakan bahwa motivasi belajar memiliki fungsi yaitu: (1) Mendorong manusia untuk berbuat yang artinya motivasi merupakan motor penggerak dari setiap kegiatan yang akan dikerjakan; (2) Menentukan arah perbuatan yang berarti 
memberikan arah yang harus dikerjakan sesuai dengan rumusan tujuan yang telah ditetapkan; (3) Menyeleksi perbuatan, yaitu memilih kegiatan yang mendukung untuk mencapai tujuan dan; (4) mendorong usaha untuk mencapai prestasi, seorang siswa yagn memiliki motivasi yang kut akan lebih rajin belajarnya sehingga hasil belajarnya akan lebih baik.

Penelitian lain yang juga mendukung adalah penelitian yang dilakukan Wati (2014:4) Hasil penelitian tersebut menunjukkan bahwa hasil belajar matematika siswa yang menerapkan model pembelajaran kooperatif tipe Inside Outside Circle lebih baik dari hasil belajar matematika siswa yang menerapkan pembelajaran biasa pada kelas VIII SMP Negeri 9 Pariaman.

Pembelajaran dengan model pembelajaran inside outside circle membuat siswa lebih senang dalam belajar karena dikemas dengan memecahkan masalah belajar. Dengan tingginya minat dan motivasi belajar yang dimiliki oleh siswa maka terbukti dengan meningkatnya hasil belajar yang didapat oleh siswa.

\section{E. SIMPULAN DAN SARAN}

Berdasarkan hasil penelitian terhadap mata pelajaran IPA dengan model pembelajaran inside outside circle dapat ditarik kesimpulan yaitu ada keefektifan hasil belajar siswa dengan menggunakan model pembelajaran inside outside circle pada mata pelajaran IPA dibandingkan dengan menggunakan pembelajaran ceramah. Hal ini terjadi karena pembelajaran dengan menggunakan model pembelajaran inside outside circle dilakukan dengan praktik langsung siswa dalam pembelajaran.

Dengan adanya pemahaman yang baik serta meningkatnya motivasi belajar siswa menjadikan hasil belajar yang diperoleh oleh siswa meningkat. Dengan meningkatnya hasil belajar siswa pada mata pelajaran IPA, diharapkan para pendidik bisa menggunakan cara yang sama untuk mata pelajaran lain dengan materi yang sesuai. Sehingga pembelajaran tidak membuat siswa bosan dan takut, tetapi belajar membuat siswa senang.

\section{DAFTAR PUSTAKA}

Barsihanor. (2016). Pengaruh Model Pembelajaran Cooperative Learning Teknik Inside Outside Circle Terhadap Hasil Belajar Siswa Bidang Studi IPS MI Darul Mujahidin. Jurnal Madrasaah Ibtidaiyah. Vol 1 (2). Halaman: 2030.

Dimyati dan Mudjiono (2009). Belajar dan Pembelajaran. Jakarta: PT Rineka Cipta.

Faradila WB, Sulistyaningsih, Dwi, Purnomo EA. (2017). Keefektifan Model Pembelajaran Inside Outside Circle Dengan Pendekatan Open Ended Terhadap Kemampuan Koneksi Matematis Kelas VIII Materi Sistem Persamaan Linier Dua Variabel. Seminar Nasional Pendidikan, Sains dan Teknologi. Fakultas Matematika dan Ilmu Pengetahuan Alam Universitas Muhammadiyah Semarang. 453459.

Kustandi, Cecep dan Bambang Sutjipto. (2011). Media Pembelajaran; Manual dan Digital. Bogor: Ghalia Indonesia.

Ningsih S, Andriani S. (2017). PENERAPAN Model Pembelajaran Inside Outside Circle Terhadap Kemampuan Pemahaman Konsep Siswa. Journal of Mathematics Education and Science Vol. 2, No. 2. Halaman: 88-94. 
PEDAGOGIA : Jurnal Ilmu Pendidikan

Panen, Paulina. (2004). Modul Belajar dan Pembelajaran $1 . \quad$ Jakarta: Universitas terbuka.

Ruhimat, Toto, dkk. (2011). Kurikulum dan Pembelajaran. Jakarta: Rajawali Pers.

Rusman. (2013). Model- model pembelajaran. Jakarta: Rajawali Pers.

Belajar dan Pembelajaran
Berbasis Komputer. Bandung: Alfabeta.

Sardiman, A.M. (2007). Ineraksi dan Motivasi Belajar Mengajar. Jakarta: PT Raja Grafindo Persada.

Shoimin. (2014). Model Pembelajaran Inovatif dalam Kurikulum 2013. Yogyakarta: Ar-Ruzz media 